\title{
Person of the Month: Alfred Adler (1870-1937)
}

\section{Ankit Patel ${ }^{1}$}

$\begin{array}{ll}\text { Born } & \text { 7 February, 1870 } \\ \text { Vienna, Austria-Hungary } \\ \text { 28 May, 1937 } \\ \text { Aberdeen, Scotland } \\ \text { Citizenship } & \begin{array}{l}\text { Austrian } \\ \text { Known for }\end{array} \\ & \begin{array}{l}\text { Individual psychology, } \\ \text { The concept of the inferiority complex, } \\ \text { President of the Vienna Psychoanalytic } \\ \text { Society, 1910 }\end{array} \\ \text { Fields } & \text { Psychotherapist, Psychiatrist }\end{array}$

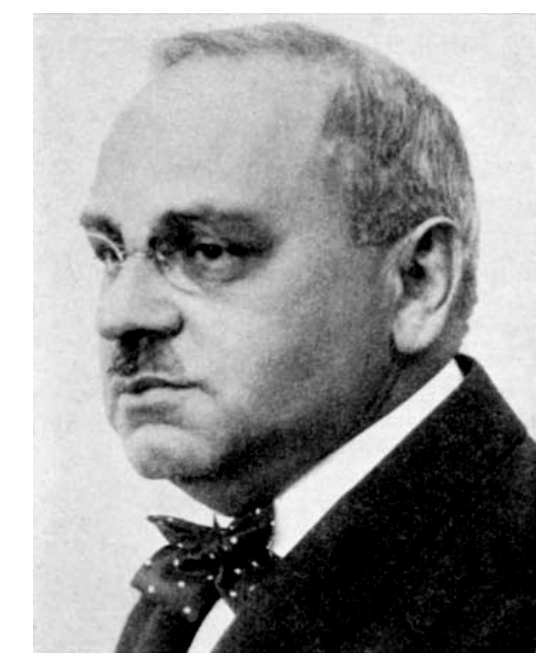

Alfred Adler is known as one of the most influential thinkers in psychology. While he was initially a member of the Vienna Psychoanalytic Society, Adler eventually departed from Freud's theories and developed his own perspective, which he called Individual Psychology. He had a strong influence on a number of other eminent psychologists, including Carl Rogers, Abraham Maslow and Karen Horney.

Alfred Adler was an Austrian doctor and therapist who is best-known for forming the school of thought known as individual psychology. He is also remembered for his concept of the inferiority complex, which he believed played a major part in the formation of personality. Alder was initially a colleague of Sigmund Freud, helped establish psychoanalysis, and was a founding member of the Vienna Psychoanalytic Society. Adler's theory focused on looking at the individual as a whole, which is why he referred to his approach as individual psychology. Adler was eventually expelled from Freud's psychoanalytic circle, but he went on to have a tremendous impact on the development of psychotherapy. He also had an important influence on many other great thinkers including Abraham Maslow and Albert Ellis.

Alfred Adler was born in Vienna, Austria. He suffered rickets as a young child which prevented him from walking until the age of four. Due to his health problems as a child, Adler decided he

\footnotetext{
${ }^{1}$ Clinical Psychology, Dept. of Psychology, Sardar Patel University, Vallabh Vidyanagar, Gujarat

(C) 2016 A Patel; licensee IJIP. This is an Open Access Research distributed under the terms of the Creative Commons Attribution License (http://creativecommons.org/licenses/by/2.0), which permits unrestricted use, distribution, and reproduction in any Medium, provided the original work is properly cited.
} 


\section{Person of the Month: Alfred Adler (1870-1937)}

would become a physician and, after graduating from the University of Vienna in 1895 with a medical degree, began his career as an ophthalmologist and later switched to general practice.

Alder soon turned his interests toward the field of psychiatry. In1902, Sigmund Freud invited him to join a psychoanalytic discussion group. This group met each Wednesday in Freud's home and would eventually grow to become the Vienna Psychoanalytic Society. After serving as President of the group for a time, Adler left in part because of his disagreements with some of Freud's theories.

While Adler had played a key role in the development of psychoanalysis, he was also one of the first major figures to break away to form his own school of thought. He was quick to point out that while he had been a colleague of Freud's, he was in no way a disciple of the famous Austrian psychiatrist. In 1912, Alfred Adler founded the Society of Individual Psychology. Adler's theory suggested that every person has a sense of inferiority. From childhood, people work toward overcoming this inferiority by asserting their superiority over others. Adler referred to this as 'striving for superiority' and believed that this drive was the motivating force behind human behaviors, emotions, and thoughts.

Although Adler's psychological theory was developed nearly a century ago, many of his concepts are still brought to fruition through Adler University. His concepts based in social interest, social justice, equality, and the importance of education guide the Adler University's commitment to social change - from our curriculum, practica, internships, programming and experiential offerings for students, faculty and alumni - to our hundreds of partnerships at work with local communities to improve community mental health.

Although Adler's theory may be less interesting than Freud's, with its sexuality, or Jung's, with its mythology, it has probably struck you as the most common-sensical of the three. Students generally like Adler and his theory. In fact, quite a few personality theorists like him, too. Maslow, for example, once said that, the older he gets, the more right Adler seems. If you have some knowledge of Carl Rogers' brand of therapy, you may have noticed how similar it is to Adler's. And a number of students of personality theories have noted that the theorists called Neo-Freudians -- Horney, Fromm, and Sullivan -- should really have been called Neo-Adlerians.

And so the "positives" of Adler's theory don't really need to be listed: His clear descriptions of people's complaints, his straight-forward and common-sense interpretations of their problems, his simple theoretical structure, his trust and even affection for the common person, all make his theory both comfortable and highly influential. 


\section{TIMELINE}

1870

1888

Alfred Adler born on February 7th 1870

1895

Began his studies at the University of Vienna Medical School

1897

Received medical degree from the University of Vienna

Married Raissa Timofeivna Epstein

1898

Established private practice in Vienna

-Birth of first daughter, Valentine

-Published two articles in Austria's "Medical News Bulletin"

1901

Second child, Alexandra, is born

1902

Published two articles in Medical News Bulletin

-Sigmund Freud invited Adler to join the fledgling Wednesday Psychological Society

1904

(later renamed to Vienna Psychoanalytic Society)

Adler publishes his most important article to date, The Physician as Educator

-Converted from Judaism to Protestanism

1905

-Birth of Kurt Adler

1909

Publication of A Study of Organ Inferiority

Birth of Cornelia (daughter)

1911

Adler is expelled from the Vienna Psychoanalytic Society under Freud's impetus

-Adler forms his own group, initially called the Society for Free Psychoanalytic Inquiry

1912

Published The Neurotic Constitution

1913

1914

Renamed his group The Society for Individual Psychology

1916

Published Healing and Education, edited by Adler

1918

Drafted as a military physician for the Austro-Hungarian Empire during World War I

Discharged from military service, began emphasizing social feeling in writings

1922

Published The Practice and Theory of Individual Psychology

-Adler begins setting up educational consulting teams in child guidance for Vienna's

public schools 
1924

1929

Became a professor at Vienna's Pedagogical Institute 1928 First lecture-tour of the United States

-Published The Case of Miss R: The Interpretation of a Life Story

Became an adjunct professor at Columbia University, started to shift base of operations from Vienna to New York City

-Published Individual Psychology in the Schools

1931

1932

Published What Life Should Mean to You

Professor at the Long Island College of Medicine, Adler's first full-time academic position in the United States

1933

Published Religion and Individual Psychology and Social Interest: A Challenge to Mankind

1937

Died, May 28th, Aberdeen, Scotland

\section{SELECTED PUBLICATIONS}

Adler, A. (1925). The Practice and Theory of Individual Psychology. London: Routledge.

Adler, A. (1956). The Individual Psychology of Alfred Adler. H. L. Ansbacher and R. R. Ansbacher (Eds.). New York: Harper Torchbooks.

\section{QUOTES}

"It is easier to fight for one's principles than to live up to them."

"The chief danger in life is that you may take too many precautions."

“The only normal people are the ones you don't know very well."

"Exaggerated sensitiveness is an expression of the feeling of inferiority."

“Trust only movement. Life happens at the level of events, not of words. Trust movement."

"We must interpret a bad temper as a sign of inferiority."

"The greater the feeling of inferiority that has been experienced, the more powerful is the urge

to conquest and the more violent the emotional agitation."

"It is the patriotic duty of every man to lie for his country."

"The educator must believe in the potential power of his pupil, and he must employ all his art in seeking to bring his pupil to experience this power."

"There is no such thing as talent. There is pressure." 


\section{REFERENCES}

Adler University, (2016), About Alfred Adler, Received from https://www.adler.edu/page/about/history/about-alfred-adler [7:59 PM, 5 April, 2016]

Adler University, (2016), Adler University Timeline, Received from https://www.adler.edu/page/about/history/timeline [7:51 PM, 5 April, 2016]

Dr. C. George Boeree (2006), ALFRED ADLER (1870 - 1937), Received from http://webspace.ship.edu/cgboer/adler.html [8:10 PM, 5 April, 2016]

Hoffman, Edward (1994), The Drive For Self: Alfred Adler And The Founding Of Individual Psychology, Addison-Wesley

Kendra Cherry (2015) Alfred Adler, Received from http://psychology.about.com/od/profilesal/p/alfred-adler.htm [7:56 PM, 5 April, 2016]

Molly Fisher (May 2001) Alfred Adler (1870 - 1937), Received from http://www.muskingum.edu/ psych/psycweb/history/adler.htm\#Time\%20Line [8:16 PM, 5 April, 2016]

Photo Credit by: Wikipedia.Org 